\title{
Roles of Xenobiotic Receptors in Vascular Pathophysiology
}

\author{
Lei Xiao, PhD; Zihui Zhang, BSc; Xiaoqin Luo, PhD
}

\begin{abstract}
The pregnane $\mathrm{X}$ receptor (PXR) and constitutive androstane receptor (CAR), 2 closely related and liver-enriched members of the nuclear receptor superfamily, and aryl hydrocarbon receptor (AhR), a nonnuclear receptor transcription factor (TF), are major receptors/TFs regulating the expression of genes for the clearance and detoxification of xenobiotics. They are hence defined as "xenobiotic receptors". Recent studies have demonstrated that PXR, CAR and AhR also regulate the expression of key proteins involved in endobiotic responses such as the metabolic homeostasis of lipids, glucose, and bile acid, and inflammatory processes. It is suggested that the functions of PXR, CAR and AhR may be closely implicated in the pathogeneses of metabolic vascular diseases, such as hyperlipidemia, atherogenesis, and hypertension. Therefore, manipulation of the activities of these receptors may provide novel strategies for the treatment of vascular diseases. Here, we review the pathophysiological roles of PXR, CAR and AhR in the vascular system. (Circ $J$ 2014; 78: 1520-1530)
\end{abstract}

Key Words: Aryl hydrocarbon receptor; Constitutive androstane receptor; Pregnane X receptor; Vascular diseases

$\mathbf{T}$ he circulation system is the major organ exposed to foreign substances, or "xenobiotics", as well as endogenous chemicals, or endobiotics, during metabolic homeostasis. Human beings are constantly exposed to potential xenobiotics from the outside environment via the gastrointestinal (food, drinking water and beverages) and respiratory (air pollutants, transportation, phthalates, polybrominated diphenyl ethers and short-chain chlorinated paraffins) tracts, and by direct skin contact or other routes (drugs and plastizers) and consumer products (perfluorinated compounds, phthalates, bisphenol A and volatile organic compounds). Endobiotic homeostasis is the balance of production and elimination of endobiotics such as lipids..$^{1-3}$ Metabolizing and eliminating toxic chemicals, including xenobiotics, ${ }^{1}$ as well as endogenous chemicals or endobiotics, in the liver, intestine and vessel wall (macrophages, endothelial cells [ECs] and smooth muscle cells) is the firstline defense system, which is conserved in nearly all animals from fruit flies to humans. ${ }^{1}$ This first step of the mechanism is called "detoxification".

The pregnane $\mathrm{X}$ receptor (PXR) and constitutive androstane receptor (CAR), 2 members of the superfamily of nuclear receptors (NRs), are well-recognized "xenobiotic sensors" and can be activated by a variety of structurally diverse chemicals. They regulate the expression of drug/xenobiotic metabolizing enzymes transcriptionally to enhance the elimination of toxic byproducts derived from endogenous metabolites and of exogenous chemicals. ${ }^{2-6}$ These metabolic enzymes are divided into 2 groups: phase I and phase II enzymes. ${ }^{7,8}$ Phase I cytochrome P450 (CYP) enzymes, including CYP 1A1,1A2, 1B1, 2A6, 2B1, 2B6, 2C9, 2C19, 4A1, 4A3, 3A4, 3A7,7A1 and $8 \mathrm{~B} 1$, belong to the monooxygenase superfamily and are high- ly expressed in liver and intestine and mainly function to catalyze the first step of detoxification.9,10 Phase II conjugation reactions are catalyzed by a large group of transferases, such as sulfotransferase (SULT), glutathione S-transferases (GSTs), UDP-glucuronosyltransferases (UGT 1A1, 1A6, 2A1, 1A3, 1A4, 2B4, 1A9) and NADPH: quinine oxidoreductase (NQOR), which conjugate polar functional groups onto xenobiotics and endobiotics to produce water-soluble, inactive metabolites suitable for biliary and urinary excretion. ${ }^{11}$

Another ligand-activated transcription factor (TF), aryl hydrocarbon receptor (AhR), which is not a member of the NRs, also binds a broad spectrum of xenobiotics. ${ }^{12} \mathrm{AhR}$ is a basic helix-loop-helix/Per-Arnt-Sim (bHLH/PAS) TF involved in the adaptive and toxic responses of xenobiotics. In contrast to the other bHLH/PAS proteins, AhR is the only member known to bind naturally occurring xenobiotics. ${ }^{13}$ Activation of cytosolic AhR by any one of a variety of environmental pollutants, such as polycyclic aromatic hydrocarbons (PAH), polychlorinated biphenyls (PCBs) and dioxins, results in translocation of AhR to the nucleus where it complexes with the AhR nuclear translocator (ARNT). ${ }^{14}$ The complex then recognizes and binds specific DNA sequences, dioxin-responsive elements (DREs), within gene promoter regions and modulates subsequent geneencoding CYPs transcription. ${ }^{15,16}$

The roles of PXR and CAR in bile acid, lipid and glucose homeostasis and inflammation have been elucidated. ${ }^{17,18} \mathrm{Be}-$ cause these pathways may be disrupted in vascular diseases and the toxins contribute to vascular damage led us to consider the potential of PXR and CAR as targets for vascular therapy. Meanwhile, numerous studies have demonstrated that PAHs and 2,3,7,8-tetrachlorodibenzo-p-dioxin's (TCDDs), which are

Received March 25, 2014; revised manuscript received April 28, 2014; accepted May 1, 2014; released online May 26, 2014

Cardiovascular Research Center (L.X., Z.Z., X.L.), Department of Public Health (X.L.), Nutrition and Food Safety Engineering Research Center of Shaanxi Province (X.L.), School of Medicine, Xi' an Jiaotong University, Xi' an, China

Mailing address: Lei Xiao, PhD, Cardiovascular Research Center, School of Medicine, Xi'an Jiaotong University, Xi'an 710061, China. E-mail: xiaolei0122@mail.xjtu.edu.cn; xiaolei.0122@163.com

ISSN-1346-9843 doi:10.1253/circj.CJ-14-0343

All rights are reserved to the Japanese Circulation Society. For permissions, please e-mail: cj@j-circ.or.jp 

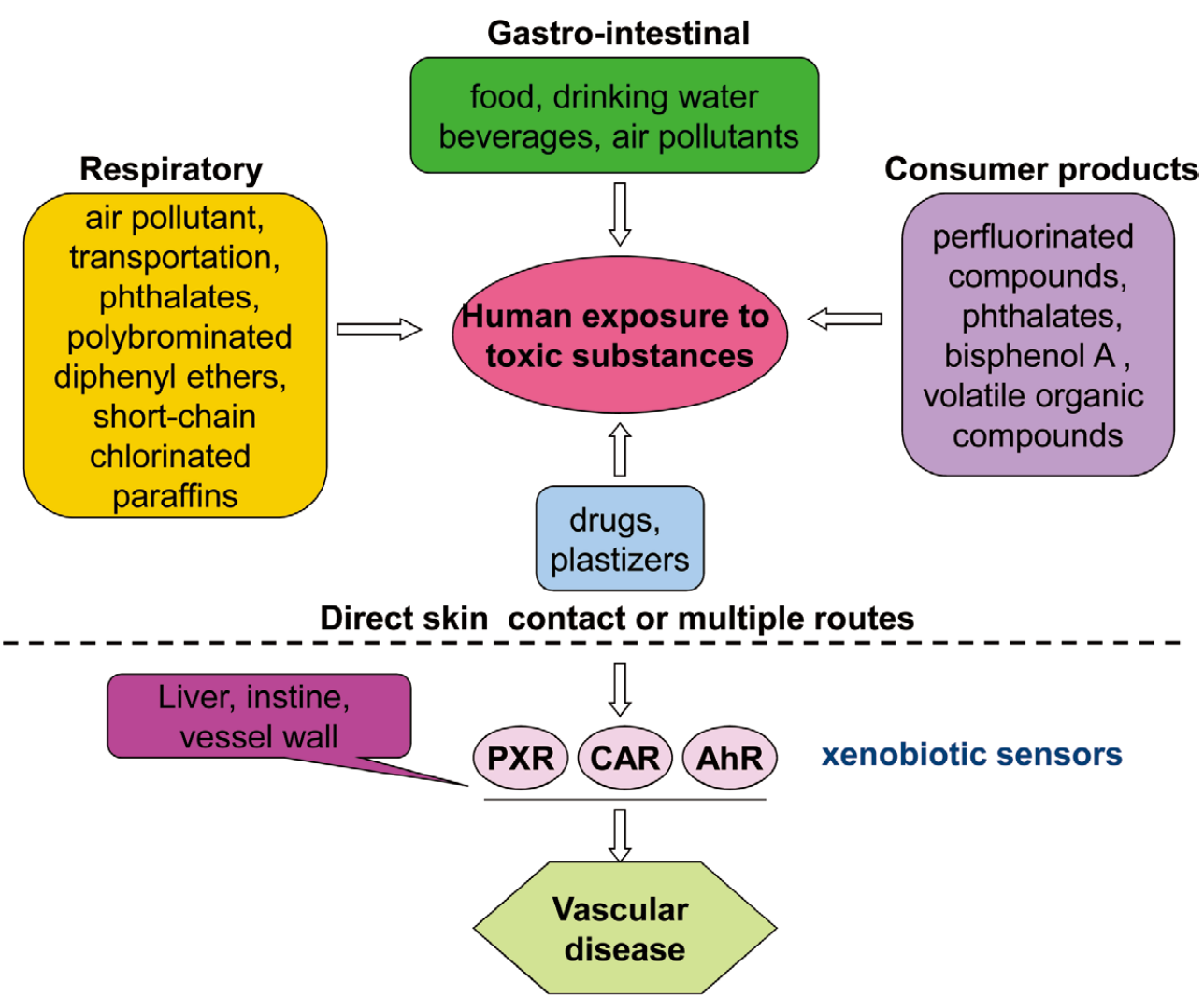

Figure 1. Schematic representation of the relationship among xenobiotics, xenobiotic sensors (ie, PXR, CAR and AhR) and vascular disease. AhR, aryl hydrocarbon receptor; CAR, constitutive androstane receptor; PXR, pregnane $X$ receptor.

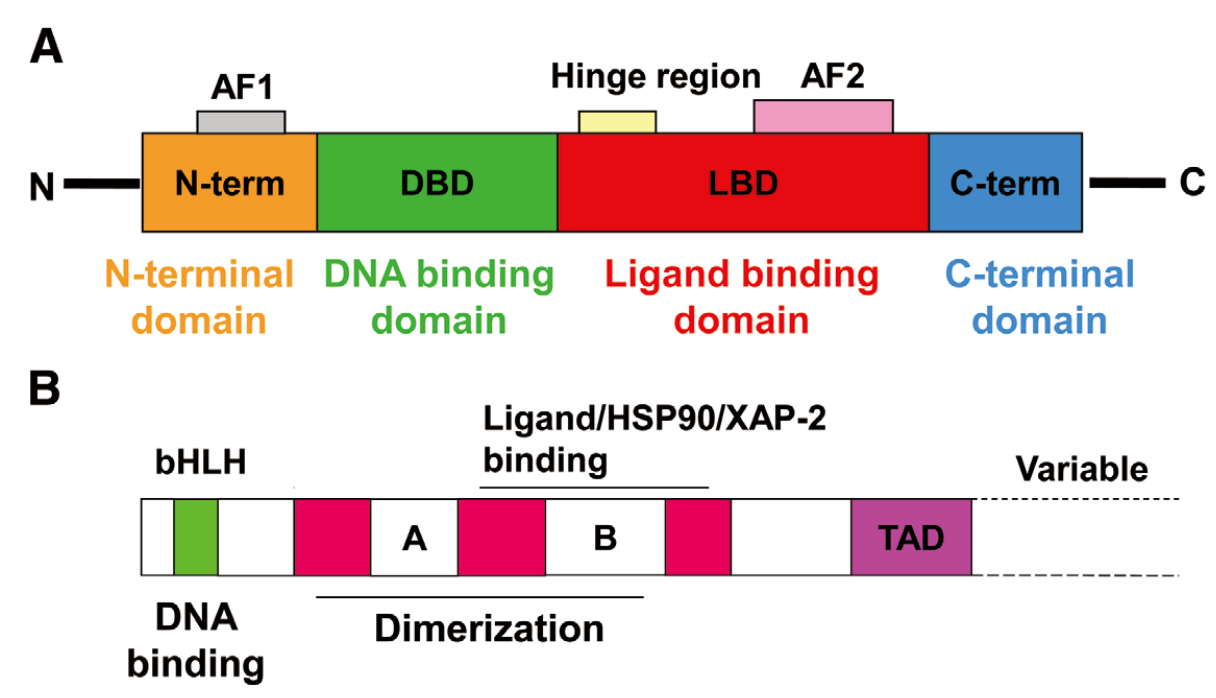

Figure 2. Schematic representation of a typical nuclear receptor and the structure of the aryl hydrocarbon receptor (AhR). (A) Nuclear receptor domain structure. Beginning at the N-terminus, nuclear receptors include the N-terminal domain, DNA binding domain (DBD), Hinge region, ligand binding domain (LBD) and C-terminal domain. (B) Domain architecture of the AhR protein. Text indicates key domain regions: NLS, nuclear localization sequence; NES, nuclear export sequence; bHLH, basic helix-loophelix domain, PAS, Per-ARNT-Sim domain (A and B repeat regions); TAD, transactivation domain. 


\begin{tabular}{|c|c|}
\hline Receptor & Ligands \\
\hline PXR & $\begin{array}{l}\text { Androstanol, coumestrol, PB, TCPOBOP, SR12813, PCN, taxol, lithocholic acid, RU486, steroids (eg, pregnenolone and } \\
\text { progesterone), cholesterol metabolites, cafestol from unfiltered coffee, bile acids, and herbal compounds such as hyperforin } \\
\text { (active constituent of St. John's Wort), guggulipid, colupulone, isoflavones; drugs such as rifampicin, clotrimazole, ritonavir, } \\
\text { metyrapone and cardiovascular drugs (eg, HMG-CoA reductase inhibitors, the 'statins') }\end{array}$ \\
\hline CAR & $\begin{array}{l}\text { PB, androstenol, clotrimazole, 5 } 3 \text {-pregnane-3,20-dione, retinoic acids, clotrimazole, CPZ, o,p'-DDT, methoxychlor, and } \\
\text { tohydrocarbons (eg, 2,3,3',4',5',6-hexachlorobiphenyl, CITCO, hCAR), PCN and TCPOBOP (in mCAR) }\end{array}$ \\
\hline AhR & $\begin{array}{l}\text { Halogenated aromatic hydrocarbons (eg, polychlorinated dibenzodioxins, dibenzofurans and biphenyls), polycyclic aromatic } \\
\text { hydrocarbons (eg, TCDD), derivatives of tryptophan, bilirubin, biliverdin, tryptamine, indole acetic acid, retinoids, tetrapyrroles, } \\
\text { and some modified low-density lipoproteins }\end{array}$ \\
\hline
\end{tabular}

AhR, aryl hydrocarbon receptor; CAR, constitutive androstane receptor; CITCO, 6-(4-chlorophenyl) imidazo [2,1-b][1,3]thiazole-5-carbaldehyde O-(3,4-dichlorobenzyl) oxime; CPZ, chlorpromazine; HMG-CoA, 3-hydroxy-3-methylglutarate-CoA; PB, phenobarbital; PCN, pregnenoIone 16a-carbonitrile; PXR, pregnane X receptor; TCDD, 2,3,7,8-tetrachlorodibenzop-dioxin; TCPOBOP, 1,4-bis[2-(3,5-dichloropyridyloxy)] benzene.

the major constituents of cigarette tobacco tar and environmental contaminants, are strongly involved in the pathogenesis of vascular diseases. Because PAH and TCDD-induced toxicities are mediated by the activation of AhR, a direct link between $\mathrm{AhR}$ and cardiovascular diseases (CVDs) exists in all probability. ${ }^{19}$ This review summarizes recent advances in elucidating the roles of PXR and CAR and AhR in vascular therapy. The relationship among xenobiotics, PXR, CAR, AhR and vascular disease are summarized in Figure $\mathbf{1 .}$

\section{Genes and Proteins of PXR, CAR and AhR}

PXR, also known as steroid and xenobiotic sensing NR (SXR) or NR subfamily 1, group I, member 2 (NR1I2), is a protein that is encoded by the NR1I2 gene in humans. ${ }^{20}$ The human PXR gene is located on chromosome 3, locus 3q12-q13.3, and spans approximately $20 \mathrm{~kb} \cdot{ }^{21,22} \mathrm{CAR}$, also known as NR subfamily 1 , group I, member 3 , is a protein that in humans is encoded by the NR1I3 gene. The human CAR gene is located on chromosome 1, locus 1q23. ${ }^{23}$ PXR and CAR, like all the members of the NRs, are modular proteins sharing common regions, including the $\mathrm{N}$-terminal DBD, the $\mathrm{H}$ region, and the $\mathrm{C}$-terminal LBD (Figure 2). AhR is a protein that in humans is encoded by the AHR gene. The human AHR gene is located on chromosome 7: $17.34-17.39 \mathrm{Mb}$. AhR is a ligand-activated transcriptional factor with the primary function of mediating xenobiotic metabolism through transcriptional activation of Phase I and Phase II drug-metabolizing enzymes, such as CYP1A1, 1A2, 1B1, UGT1A1 and UGT1A6, GSTA2, aldehyde dehydrogenase 3 (ALDH3), or NQOR. ${ }^{5,24,25}$ AhR also share some common target genes with PXR and CAR, such as CYP1A2 and UGT1A1.26 AhR is the only protein in the bHLH/PAS superfamily that requires activation by an exogenous ligand.

\section{Ligands and Functions of PXR, CAR and AhR}

PXR is activated by a large number of endogenous and exogenous chemicals including androstanol, coumestrol, phenobarbital (PB), 1,4-bis[2-(3,5-dichloropyridyloxy)]benzene (TCPOBOP), SR12813, pregnenolone $16 \alpha$-carbonitrile (PCN), taxol, lithocholic acid, mifepristone (RU486), steroids (pregnenolone and progesterone), cholesterol metabolites, cafestol from unfiltered coffee, bile acids, and many other herbal compounds such as hyperforin (active constituent of St. John's Wort), guggulipid, colupulone, and isoflavones..22,27 PXR is also activated by widely used pharmaceutical drugs including rifampicin (antibiotic), clotrimazole (antimycotic), ritonavir, metyrapone and cardiovascular drugs such as the HMG-CoA reductase inhibitors (statins). ${ }^{28,29} \mathrm{CAR}$ can be activated by a variety of compounds including $\mathrm{PB}$, androstenol, clotrimazole, $5 \beta$-pregnane-3, 20-dione, retinoic acids, clotrimazole, chlorpromazine (CPZ), o,p'-DDT, methoxychlor, and tohydrocarbons such as 2,3,3',4',5',6-hexachlorobiphenyl, 6-(4-chlorophenyl) imidazo [2,1-b][1,3] thiazole-5-carbaldehyde O-(3,4-dichlorobenzyl) oxime (CITCO, hCAR), PCN and TCPOBOP (in mCAR). ${ }^{27,30-33}$ Although CAR and PXR share some common ligands and also have an overlapping target gene pattern, ${ }^{27,34-36}$ the mode of activation for these 2 receptors is quite different. PXR is located in the nucleus with a low basal activity and is highly activated upon ligand binding. ${ }^{22,36}$ Unlike PXR, CAR resides in the cytoplasm in the non-induced state ${ }^{9}$ and is constitutively active in the absence of ligand and regulated by both agonists and inverse agonists. Ligand binding results in translocation of this protein to the nucleus, where it activates or represses target gene transcription. The constitutive activity of CAR was thought to be related to the ligand-independent recruitment of NR coactivators by CAR. ${ }^{37}$ PXR and CAR regulate gene expression by forming heterodimers with the retinoid X receptor (RXR, NR1B2).

Above all, PXR can be activated by pregnanes, progesterone, and glucocorticoids, whereas CAR is affected by androstane metabolites, estrogens, and progesterone. ${ }^{38,39}$ For this reason, in addition to functioning as xenobiotic receptors, PXR and CAR are thought to be endobiotic receptors that influence some physiology and diseases. ${ }^{5,40}$ PXR activity is also intricately regulated by phosphorylation, SUMOylation and lysine acetylation. Similar to PXR, CAR's activity is also regulated by phosphorylation. ${ }^{41-44}$

The synthetic ligands of AhR are some members of the halogenated aromatic hydrocarbons, such as PCBs, polychlorinated dibenzodioxins (PCDDs) and 2,3,7,8-tetrachlorodibenzop-dioxin (TCDD). ${ }^{45,46}$ Naturally occurring compounds that have been identified as ligands of AhR include derivatives of tryptophan, bilirubin, biliverdin, tryptamine, indole acetic acid, retinoids, tetrapyrroles, and some modified low-density lipoproteins (LDLs). ${ }^{27,47-49}$ Upon ligand binding, AhR translocates to the nucleus and dimerizes with ARNT. The activated AhR/ ARNT heterodimer complex is then capable of either directly or indirectly interacting with DNA by binding to DREs in promoter regions. ${ }^{50}$

In the absence of these ligands, AhR exists primarily in the cytoplasm as an inactive complex with $290-\mathrm{kDa}$ heat-shock proteins (HSP90), $1 \mathrm{X}$-associated protein (XAP), and 1 p23 molecular chaperone protein. ${ }^{51}$

Xenobiotic receptors and activation compounds are summarized in Table. The signaling pathways of PXR, CAR and 


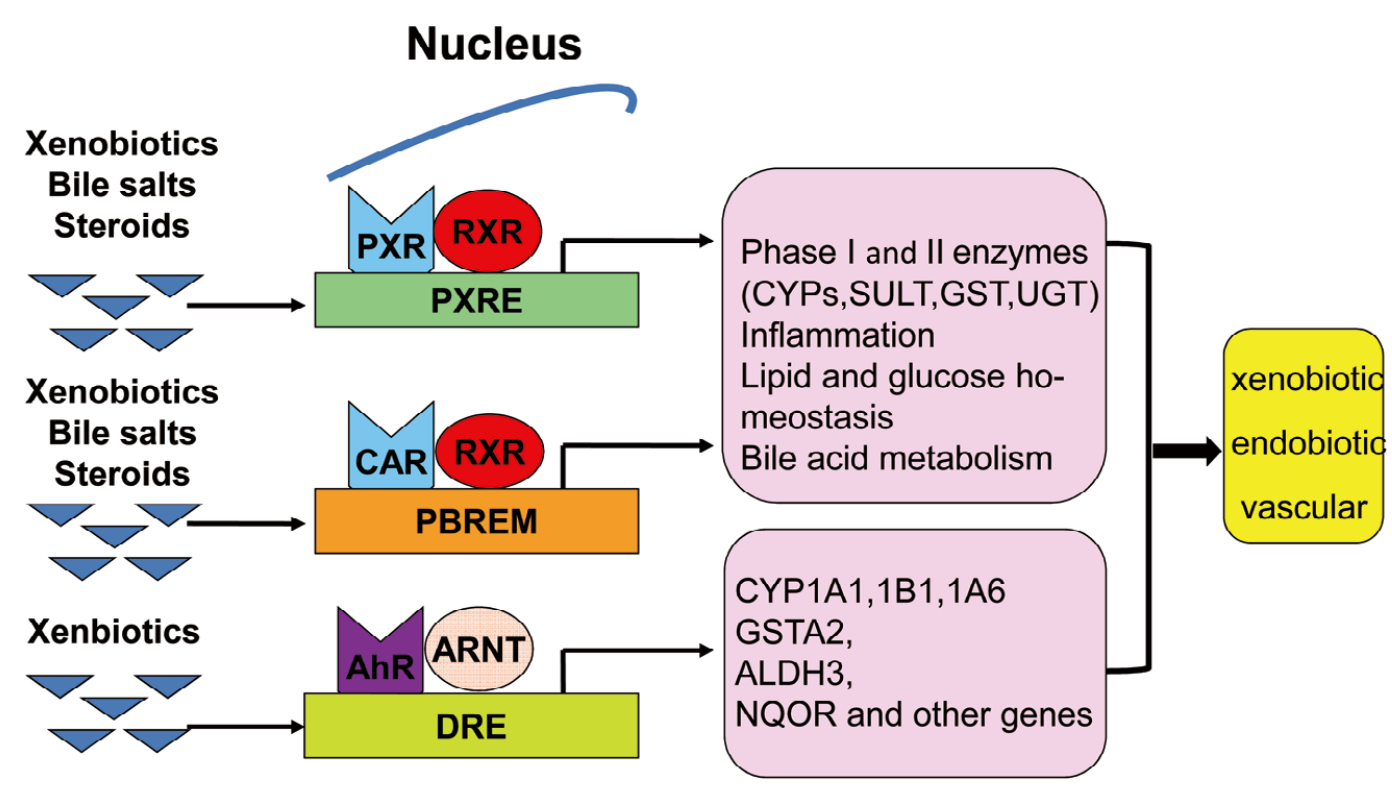

Figure 3. Summary of signaling pathways of the pregnane $X$ receptor (PXR), the constitutive androstane receptor (CAR) and the aryl hydrocarbon receptor (AhR). Upon ligand binding to PXR and CAR, the xenosensor translocates into the nucleus, thus activating gene transcription, as the PXR/RXR or CAR/RXR heterodimer. PXR and CAR mediate gene regulation through certain direct repeats, known as the PXR responsive element (PXRRE) and the PB responsive element module (PBREM). Among those that are subject to PXR and CAR regulation are a number of genes encoding phase I/II drug-metabolizing enzymes or transporters and other genes related to inflammation, lipid and glucose homeostasis and bile acid metabolism. When the ligands bind to AhR, it undergoes a conformational change whereby it translocates into the nucleus and heterodimerizes with ARNT. The AHR-ARNT heterodimer is then capable of binding its DNA element, termed the dioxin responsive element (DRE) and regulating gene transcription. Target genes that contain DREs in their promoters can be regulated by AhR. Among those that are subject to AhR regulation are a number of genes encoding phase I/ll drug-metabolizing enzymes or transporters, ALDH3, NQOR and other genes.

AhR are shown in Figure 3.

\section{PXR, CAR and Vascular Disease}

In addition to their conventional roles in xenobiotic metabolism, PXR and CAR have been found in the vasculature where they regulate vascular function, inflammation, bile acid metabolism, lipid and glucose homeostasis. ${ }^{52}$

\section{PXR and CAR in Drug Metabolism}

PXR regulates the genes involved in drug and xenobiotic metabolism, including CYPs, GSTs, multidrug resistance protein 1 (MDR1) and SULTs. ${ }^{17}$ The circulation can be a hostile milieu, with increased concentrations of xenobiotics and endobiotics resulting from drugs, chemical agents, smoking, air pollution, nutritional metabolites, and pathogenic microbes or their toxins. ${ }^{53}$ These circulating endogenous and foreign chemicals can contribute to vascular dysfunction and the development of vascular disease..$^{54}$ Recent studies have demonstrated that PXR is not only expressed in the liver and intestine and its role in detoxification is not liver and intestine specific. PXR and numerous CYPs are also present in human, rat and mouse blood vessels and human and rat aortic endothelial and smooth muscle cells. ${ }^{54,55}$ PXR regulates Phase I drug metabolism (CYP3A4, CYP2B6, and CYP2C8) and MDR1 in human vascular cells. In addition, PXR ligands also induce the expression of GSTM1 to decrease oxidative stress in vascular cells. ${ }^{54}$ Our recent research also indicated that PXR represented a flow-activated detoxification system protecting ECs against damage by xeno- and endobiotics. Laminar shear stress (LSS), the atheroprotective flow, activated PXR in ECs, whereas oscillatory shear stress, the atheroprone flow, suppressed PXR. LSS-activated PXR protects ECs from apoptosis triggered by doxorubicin via the induction of MDR1 and other detoxification genes. PXR can also stimulate defense mechanisms against oxidative stress, promoting cell survival. Meanwhile, human vascular cells and macrophages express CAR, which links diet to toxicity and immunity by being involved in the bioactivation, detoxification, and transport of various drugs, xenobiotics, endogenous substances and environmental toxins. As such, this means that the body is able to prevent circulating toxins from accessing organs and that the vasculature is capable of protecting itself against damaging insults.

\section{Antimetabolic Inflammation of PXR}

Excess nutrients and the ensuing obesity can lead to a status of chronic low-grade inflammation, so-called "metabolic inflammation". Metabolic inflammation is a coordinated response to harmful stimuli that involves many components of the classical inflammatory response to pathogens and includes systemic increases in circulating inflammatory cytokines and acute phase proteins (eg, C-reactive protein [CRP]), recruitment of leukocytes to inflamed tissues, activation of tissue leukocytes, and generation of reparative tissue responses. ${ }^{56}$ Metabolic inflammation has been widely recognized as playing a critical role in the initiation, propagation, and development of metabolic diseases such as obesity, diabetes, hypertension and atherosclerosis. ${ }^{1}$ Recently, we found that PXR can suppress the expres- 
sion of proinflammatory adhesion molecules, such as vascular cell adhesion molecule-1 (VCAM-1) and endothelial leukocyte adhesion molecule-1 (ELAM-1, otherwise known as E-selectin) in response to tumor necrosis factor- $\alpha$ (TNF- $\alpha$ ) and lipopolysaccharide (LPS) in ECs. ${ }^{53}$ Overexpression of a constitutively active PXR in rat carotid arteries also potently attenuated proinflammatory responses. ${ }^{53} \mathrm{PXR}$ is also expressed in classical immunocytes including monocytes/macrophages and lymphocytes (both T and B cells) and inhibits inflammation. ${ }^{57-59}$ LPS, interleukin-6 (IL-6) and endotoxin all downregulate the expression of PXR and its target genes. ${ }^{60,61}$ The potent human PXR activator, rifampicin, suppresses the expression of typical nuclear factor $\kappa \mathrm{B}(\mathrm{NF}-\kappa \mathrm{B})$ target genes, such as cyclooxygenase-2 (COX-2), TNF- $\alpha$, intercellular adhesion molecule 1 (ICAM-1), and IL-1, 2, 6, and 15 in human hepatocytes. ${ }^{62}$ Inflammatory signals also modify PXR at the post-translational level. A recent study showed that the inflammatory response to TNF- $\alpha$ caused SUMOylation of PXR to inhibit the activation of NF- $\kappa \mathrm{B} \cdot{ }^{57}$

\section{PXR and CAR in the Metabolism of Bile Acids}

Bile acids are the endproducts of cholesterol utilization and can be extremely toxic if their levels become elevated. Bile acids aid the absorption of dietary fats, via active uptake from the intestines and enterohepatic circulation. ${ }^{63}$ The relationship between bile acids and vascular disease has been a recent focus of investigation. Sequestering bile acids in the intestinal lumen or preventing their uptake is used therapeutically to lower LDL cholesterol, an independent risk factor for vascular diseases. ${ }^{64}$

PXR and CAR activation in hepatocytes is protective against hepatotoxicity induced by bile acids. ${ }^{65-67}$ Accumulation of bile acid and bile acid precursors directly leads to PXR activation. ${ }^{68,69}$ PXR regulates the metabolism of bile acids by (1) decreasing the synthesis of bile acid; (2) increasing bile acid catabolism; and (3) promoting the hepatic uptake of bile acids from the blood and their excretion into bile. The PXR-regulated target genes involving these processes include metabolizing enzymes such as CYP3A11, SULT2A, the transporter multidrug resistance-associated protein3 (MRP3), organic anion transporting polypeptide (OATP2), solute carrier organic anion transporter family member 1B1 (SLCO1B1), adenosine triphosphate (ATP)-binding cassette subfamily B 11 (ABCB11), ATP-binding cassette subfamily $\mathrm{C} 2$ (ABCC2) and CYP7A $1 .{ }^{17}$ CAR can downregulate OATP1A1 and upregulate OATP1A4 and MRPs mRNA expressions to promote bile acids efflux from the hepatocytes. ${ }^{70-72} \mathrm{CAR}$ also can increase the mRNA expression of efflux transporters (bile salt export pump [BSEP], breast cancer resistance protein [BCRP], MRP2, MRP3, and MDR1) and decrease the levels of uptake transporters (OATP1B3, OAT2, Na+/taurocholate cotransporting polypeptide $[\mathrm{NTCP}])^{73-76}$ in human hepatocytes. This CAR role occurs in the absence of the key bile acid sensors, FXR and PXR. ${ }^{77,78}$ Therefore, PXR and CAR may offer a target to effectively reduce bile acids and thus limit LDL cholesterol levels.

\section{PXR and CAR in Lipid and Glucose Homeostasis}

A number of clinical observations have shown that many drugs, identified as PXR and/or CAR activators, affect lipid or/and glucose metabolism in patients. The liver plays a critical role in maintaining blood lipid and glucose homeostasis. PXR and CAR can promote hepatic lipogenesis by downregulating genes involved in lipid oxidation such as carnitine palmitoyltransferase-1A (CPT-1A) and mitochondrial 3-hydroxy3 -methylglutarate-CoA synthase-2 (HMGCS2) and pro- $\beta$ - oxidation proteins, peroxisome proliferator activated receptor (PPAR)- $\alpha$ and thiolase. ${ }^{79-82}$ PXR activation causes hepatic steatosis and induces the expression of CD 36 (a fatty acid translocase involved in long-chain fatty acid [LCFA] transport). ${ }^{55,81} \mathrm{PXR}$ also upregulates stearoyl-CoA-desaturase-1 (SCD-1), spot 14 and PPAR- $\gamma{ }^{69,82}$ CAR agonist, PB, decreases the enoyl CoA isomerase (ECI) mRNA. In addition, CAR and PXR directly affect lipogenic pathways by activating Insig-1, an endoplasmic reticulum (ER) protein involved in sterol-dependent synthesis of cholesterol. ${ }^{83}$ PXR agonists do not induce lipogenesis in rat vascular smooth muscle. ${ }^{84}$

Diabetes and prediabetic-elevated plasma glucose levels are risk factors for CVD. Genes involved in gluconeogenesis notably include phosphoenolpyruvate carboxykinase (PEPCK) and glucose-6-phosphatase (G6Pase). Activation of PXR in fasting mice decreases serum glucose and suppresses the expression of PEPCK and G6Pase. ${ }^{82}$ PB has been shown to decrease plasma glucose levels and improve insulin sensitivity in diabetic patients. ${ }^{85}$ Activation of CAR represses the expression of PEPCK by competition with hepatocyte nuclear factor $4 \alpha(\mathrm{HNF} 4 \alpha)$ for the binding of a DR1 element within the PEPCK gene promoter and the inhibition of HNF $4 \alpha$ transcriptional activity by the squelching of PPAR- $\gamma$ coactivator $1 \alpha$ $(\mathrm{PGC} 1 \alpha) .{ }^{86}$ Forkhead box protein $\mathrm{O} 1$ (FoxO1) positively controls the expression of genes involved in gluconeogenesis and it represents the target of insulin's repressive action on the gluconeogenesis pathway. PXR and CAR can repress the transcriptional activity of FoxO1 by preventing its binding to its responsive element IRS in target gene promoters such as PEPCK and G6Pase, ${ }^{18}$ implicating PXR and CAR as negative transcriptional regulator of genes involved in glucose metabolism.

\section{AhR and Vascular Disease}

The AhR protein is expressed in most tissues, with the highest mRNA and protein levels found in the lung, liver, kidney, and placenta, and lower levels in the heart and endothelium. ${ }^{87-89}$ Activation of AhR signaling is recognized as the body's primary molecular defense following environmental toxicant exposure. ${ }^{90-92}$ Exposures to AhR ligands can lead to some major metabolic diseases including vascular disease and cancer..$^{93-97}$

\section{AhR and Atherosclerosis}

Atherosclerosis is considered a chronic inflammatory disease of the vessel wall characterized by chemokine-driven mononuclear cell recruitment into the subendothelial space, where the mononuclear cells differentiate into macrophages. ${ }^{45}$ Macrophages and ECs play key roles in atherogenesis by releasing proinflammatory cytokines and forming foam cells in subendothelial lesions. ${ }^{98}$ Exposure to some AhR ligands (eg, dioxins, TCDD, PAH) causes inflammatory responses in macrophages and may lead to the formation of foam cells ${ }^{93,98}$ and is associated with progression of atherosclerosis. ${ }^{99}$

Exposure of $\mathrm{ApoE}^{-/-}$mice to TCDD time-dependently accelerated the progression of atherosclerosis. TCDD promotes foam cell formation and induces the expression of inflammatory mediators including NF- $\kappa \mathrm{B}, \mathrm{COX}-2, \mathrm{IL}-1 \beta, \mathrm{TNF}-\alpha, \mathrm{IL}-8$ and metalloproteinase 12 (MMP-12). ${ }^{93}$ Urban dust also activates $\mathrm{AhR}$ and increases the production of CRP and IL-6 in human macrophages. ${ }^{98,100}$ TCDD-induced inflammation can be further enhanced by a high-fat diet in mice and deteriorates the formation of complex atheromas. Conversely, the AhR antagonist, TCDD, significantly suppresses the expressions of COX-2 and CYP1A1 induced by these particles and their organic extracts. ${ }^{98}$ Recently, the IL-8 receptor (IL8R), also known 


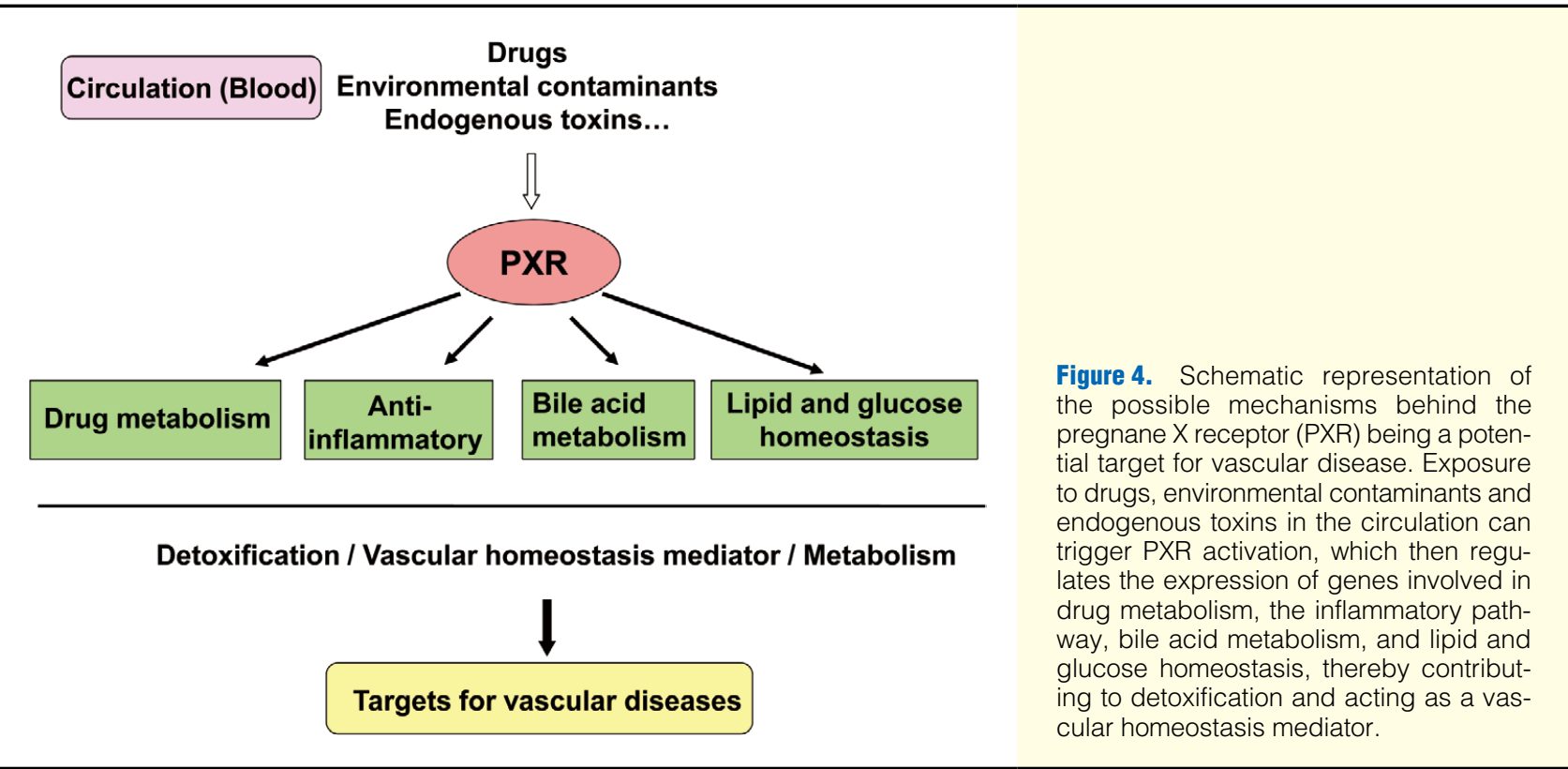

as CXCR2 (a G protein-coupled receptor), was implicated as a contributory factor and is considered to play a pivotal role in inflammatory diseases ${ }^{51}$ and ultimately, production of the CXCR2 target gene VEGF mediates the atherogenic activity of environmental pollutants through the induction of a vascular inflammatory response by activating the AhR-signaling pathway. ${ }^{101,102}$

Besides the function of macrophages, vascular endothelial dysfunction is the initiation step in atherosclerogenesis, which is characterized by increased adhesiveness caused by the presentation of cellular adhesion molecules, such as ICAM-1 and VCAM-1. ${ }^{103,104}$ By regulating AP-1, MEK and p38-MAPK, benzo[a]pyrene (BP) is able to increase ICAM-1 protein only after pretreatment with an AhR agonist, $\beta$-naphthoflavone $(\beta$ NF). ${ }^{105}$ Indoxyl sulfate (IS), an endogenous agonist for AhR, induces monocyte chemoattractant protein-1 (MCP-1) expression through reactive oxygen species production in human umbilical vein ECs and contributes to the development of atherogenesis. ${ }^{106}$ These studies strongly support the hypothesis that AhR may be a therapeutic target for downregulation of vascular inflammatory responses such as atherosclerosis. ${ }^{16}$

\section{AhR and Hypertension}

A recent study conducted by researchers at Boston University found that increased exposure to air pollution makes humans more prone to developing hypertension. ${ }^{107}$ AhR and AhR-regulated phase I/II genes in the endothelium are critically involved in blood pressure regulation and are required to maintain normal basal levels of blood pressure. ${ }^{108}$ The AhR agonist, TCDD, induces high blood pressure and AhR-mediated CYP overexpression. ${ }^{109-113}$ AhR null mice have significantly elevated mean arterial pressures (MAP) as well as increased circulating angiotensin II (AngII) and plasma endothelin-1 (ET-1) levels. ${ }^{114}$ Hypotensive $\mathrm{AhR}^{-/-}$mice exhibit a significantly higher level of endothelial nitric oxide synthase (eNOS) and enhanced vascular nitric oxide (NO) production. ${ }^{115}$ TCDD exposure of ECs increases the production of ROS, and decreases acetylcholine-stimulated NO production by inducing CYP1A1 and CYP1B1.116 AhR could serve as a target in the treatment of high blood pressure and other NO-dependent vascular diseases.

Recently, it was reported that AhR signaling played an important role in regulatory T cells. AhR participates in Th17 cell differentiation through regulating Stat 1 activation. ${ }^{117} \mathrm{~T}$ cells also play important roles in hypertension. Mice lacking T cells have blunted hypertension during AngII infusion. Hypertension increased the T-lymphocyte production of TNF- $\alpha$, and inhibited TNF- $\alpha$ could prevent the hypertension caused by AngII. ${ }^{118}$ These results indicate that AhR signaling in T cells might be a novel therapeutic target for the treatment of high blood pressure.

\section{Clinical Importance of PXR, CAR and AhR}

Drug uptake transporters are now increasingly recognized as clinically relevant determinants of variable drug responsiveness and unexpected drug-drug interactions. Activation of these transporters during vascular therapy is likely to affect the effectiveness of many drugs and there is growing evidence for tissuespecific enhancement of the malignant phenotype. ${ }^{119,120}$ Exposure to some environmental factors (xenobiotics), such as pesticides and toxic compounds, has been shown to play an important role in the pathogenesis of vascular disease. The enzymes implicated in xenobiotic metabolism are regulated by an endogenous defense system comprising PXR, CAR and AhR. Both their levels and functional structures are determined by their coding genes or other molecules regulating their expressions. With the revelation of human genome sequences and frequency of sequence variations in the population, it is clear that the DNA sequences of these genes vary from subject to subject. Thus, genetic variation in these TFs may modify the regulation of relevant environmental factors and the associated risk of vascular disease. Genes in the CYP superfamily are highly polymorphic and mutations in CYP1A1, 1B1, CYP2A, 2B, 2C, 2E 2J, CYP3A, CYP4A, 4B, 4F, CYP5A1, CYP7A1, 7B1 and CYP8A1 are associated with vascular disease. ${ }^{121-123}$ Clopidogrel was selected for testing whether PXR regulation of vascular drug-metabolizing enzymes has a functional effect on the efficacy of cardiovascular drugs directly in the vessel wall. ${ }^{22,124,125}$ Clinical observations showed that PXR activation enhanced 


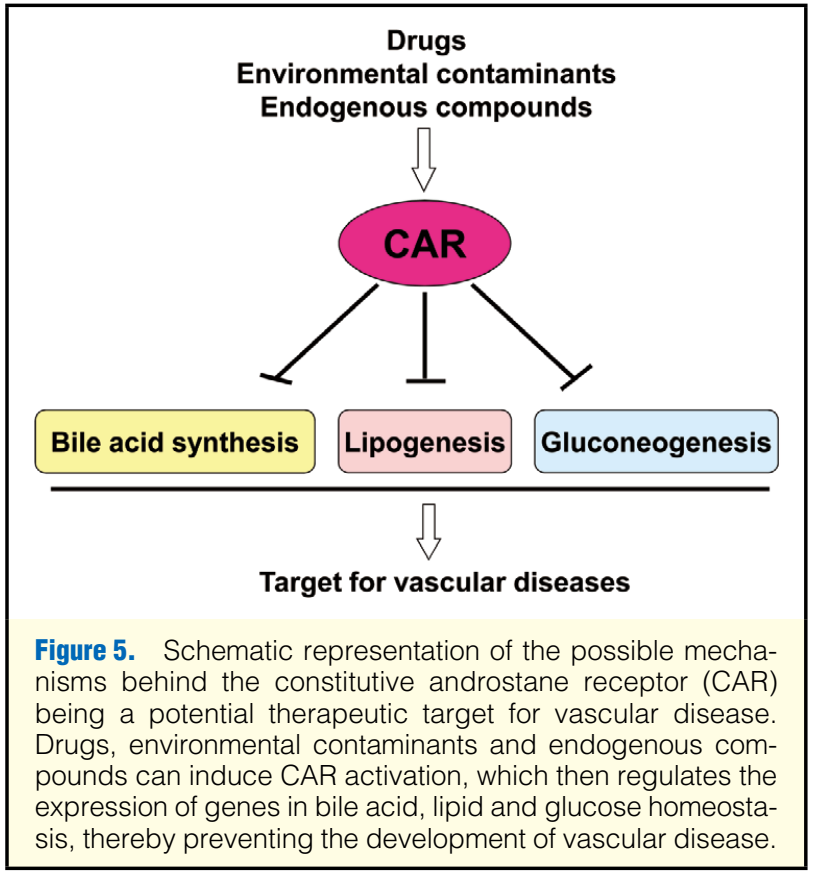

responsiveness to clopidogrel. Polymorphic PXR expression correlates with clopidogrel non-responsiveness. The allelic variant CYP2C19*17 increases the bioactivation and patient responsiveness to clopidogrel. Hagedorn et al indicated that activation of PXR by progesterone metabolites, PXR-dependently increases vasorelaxation in pregnancy. ${ }^{126}$

Some endogenous substances and other naturally occurring compounds also act as ligands for PXR and CAR. ${ }^{4}$ The initial discovery was that St. John's Wort and yin zhi huang are capable of activating PXR and CAR. ${ }^{127,128}$ Salvia miltiorrhiza, also known as danshen, has been reported to activate human PXR transcriptional activity to treat various vascular diseases, including hypertension, stroke, and hyperlipidemia. ${ }^{129,130}$ Garlic, guggul and Ginkgo biloba, commonly known as herbal medicines, are characterized as activators of CAR, which provides a molecular basis for the traditional therapeutic use of this herbal medicine in the treatment of many metabolic diseases. ${ }^{131} \mathrm{AhR}$ alter the metabolism and pharmacokinetics of some drugs, ${ }^{132}$ which has implications for clinical practice. Flavonoids are present in fruits, vegetables, and beverages derived from plants, such as tea and red wine, which have been recognized as healthpromoting and atherosclerotic vascular disease-preventing dietary supplements. ${ }^{133}$ Flavonoids inhibit the activity of CYP1A1, 1A2, 2E1, and 3A4. ${ }^{134}$ Sulforaphane (SFN) present in cruciferous vegetables shows a protective effect on inflammatory damage induced by LPS in human vascular ECs. ${ }^{135}$ SFN revealed activation of AhR transformation and induced CYP1A1 mRNA expression. ${ }^{136}$ Besides the exogenous compounds, various classes of endogenous compounds, such as eicosanoids, indirubin, bilirubin, biliverdin, tryptophan and cAMP, are able to activate AhR and thus play vital roles in vascular health and the immune system. ${ }^{49,137-140}$

\section{Conclusions}

Recent findings from many laboratories have clearly suggested that the xenobiotic NRs, PXR and CAR, not only have their "conventional" functions, but also have interesting crosstalk in their participation in drug metabolism, inflammation, lipid and

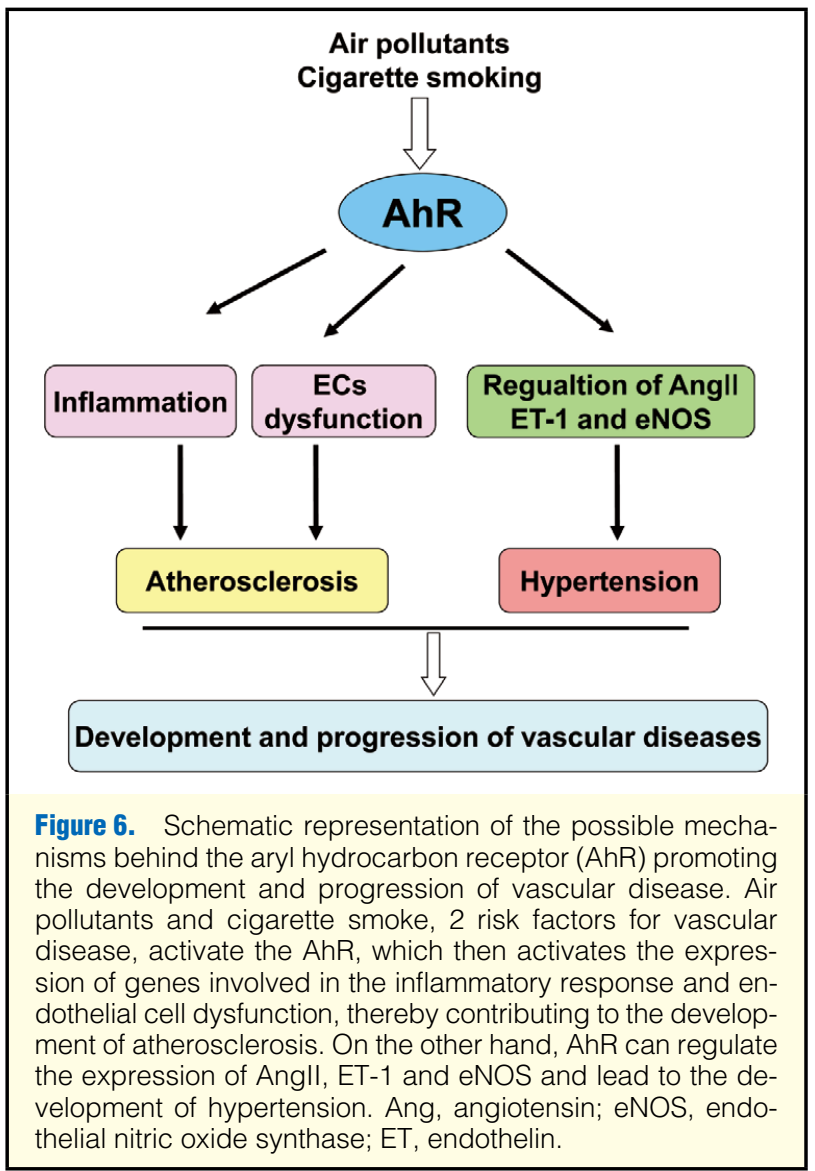

glucose homeostasis and bile acid metabolism. These discoveries suggest PXR as a novel target for vascular diseases through protection from circulating toxins and oxidative stress, antiinflammatory role and promoting bile acid and cholesterol metabolism and efflux. The health or vascular benefits of a number of natural products or drugs (eg, statins) may, in part, be via vascular PXR activation (Figure 4). Local upregulation of CYPs in the vasculature suggests that generally PXR may protect the vasculature from disruptions to vascular homeostasis and inflammation, and regulate tone. Zhou et al found that PXR activation in wild-type mice increased the levels of the atherogenic lipoproteins, very-low-density lipoprotein (VLDL) and LDL, whereas in $\mathrm{ApoE}^{-/-}$mice, PXR increased atherosclerosis by diminishing the levels of the antiatherogenic ApoAIV and increasing lipid accumulation in macrophages. ${ }^{141}$ The therapeutic potential of CAR in vascular disease, however, remains to be defined (Figure 5). CAR has been determined as a potential target in the prevention and treatment of atherosclerosis. ${ }^{142}$ However, there is limited information on the relative contribution of CAR in reduction of atherosclerosis systemically vs. locally in the vessel wall because the vasculature system expresses all AhR-regulated genes in a species- and tissue-specific manner. Nowadays, genetic, clinical and basic scientific studies all support the theory that AhR activation contributes to the development and progression of atherosclerosis and hypertension (Figure 6). AhR is also a link between the development of CVD and the "detoxification" system. Therefore, PXR, CAR and AhR have the potential to be both novel therapeutic targets for vascular disorders and be utilized by a number of current drugs and natural products to give vascular protection. 


\section{Acknowledgments}

We thank Professor Nanping Wang, Xi'an Jiaotong University Cardiovascular Research Center for helpful discussions and suggestions. We also apologize for omitting many worthy references because of space limitations.

\section{Grants}

Research projects from the laboratory of the authors were supported by National Natural Science Foundation Grants 81300242, 81220108005 and 81302426

\section{References}

1. Gao J, Xie W. Targeting xenobiotic receptors PXR and CAR for metabolic diseases. Trends Pharmacol Sci 2012; 33: 552-558.

2. Fuhr U. Induction of drug metabolising enzymes: Pharmacokinetic and toxicological consequences in humans. Clin Pharmacokinet 2000; 38: 493-504.

3. Dixit SG, Tirona RG, Kim RB. Beyond CAR and PXR. Curr Drug Metab 2005; 6: 385-397.

4. Chang TK, Waxman DJ. Synthetic drugs and natural products as modulators of constitutive androstane receptor (CAR) and pregnane X receptor (PXR). Drug Metab Rev 2006; 38: 51-73.

5. Moreau A, Vilarem MJ, Maurel P, Pascussi JM. Xenoreceptors CAR and PXR activation and consequences on lipid metabolism, glucose homeostasis, and inflammatory response. Mol Pharm 2008; 5: $35-41$.

6. Francis GA, Fayard E, PiCARd F, Auwerx J. Nuclear receptors and the control of metabolism. Annu Rev Physiol 2003; 65: 261-311.

7. Rendic S, Di Carlo FJ. Human cytochrome p450 enzymes: A status report summarizing their reactions, substrates, inducers, and inhibitors. Drug Metab Rev 1997; 29: 413-580.

8. Oesch F, Herrero ME, Hengstler JG, Lohmann M, Arand M. Metabolic detoxification: Implications for thresholds. Toxicol Pathol 2000; 28: 382-387.

9. Handschin C, Meyer UA. Regulatory network of lipid-sensing nuclear receptors: Roles for CAR, PXR, LXR, and FXR. Arch Biochem Biophys 2005; 433: 387-396.

10. Willson TM, Kliewer SA. PXR, CAR and drug metabolism. Nat Rev Drug Discov 2002; 1: 259-266.

11. McCarver DG, Hines RN. The ontogeny of human drug-metabolizing enzymes: Phase II conjugation enzymes and regulatory mechanisms. J Pharmacol Exp Ther 2002; 300: 361 - 366.

12. Tolson AH, Wang H. Regulation of drug-metabolizing enzymes by xenobiotic receptors: PXR and CAR. Adv Drug Deliv Rev 2010; 62: $1238-1249$

13. Hao N, Whitelaw ML. The emerging roles of AHR in physiology and immunity. Biochem Pharmacol 2013; 86: 561-570.

14. Hoffman EC, Reyes H, Chu FF, Sander F, Conley LH, Brooks BA, et al. Cloning of a factor required for activity of the Ah (dioxin) receptor. Science 1991; 252: 954-958.

15. Fujisawa-Sehara A, Sogawa K, Yamane M, Fujii-Kuriyama Y. Characterization of xenobiotic responsive elements upstream from the drug-metabolizing cytochrome p-450c gene: A similarity to glucocorticoid regulatory elements. Nucleic Acids Res 1987; 15: 4179-4191.

16. Sherr DH. Another important biological function for the aryl hydrocarbon receptor. Arterioscler Thromb Vasc Biol 2011; 31: $1247-$ 1248 .

17. Ihunnah CA, Jiang M, Xie W. Nuclear receptor PXR, transcriptional circuits and metabolic relevance. Biochim Biophys Acta 2011; 1812: 956-963.

18. Kodama S, Koike C, Negishi M, Yamamoto Y. Nuclear receptors CAR and PXR cross talk with FOXO1 to regulate genes that encode drug-metabolizing and gluconeogenic enzymes. Mol Cell Biol 2004; 24: $7931-7940$.

19. Korashy HM, El-Kadi AO. The role of aryl hydrocarbon receptor in the pathogenesis of cardiovascular diseases. Drug Metab Rev 2006; 38: $411-450$.

20. Bertilsson G, Heidrich J, Svensson K, Asman M, Jendeberg L, Sydow-Backman M, et al. Identification of a human nuclear receptor defines a new signaling pathway for CYP3a induction. Proc Natl Acad Sci USA 1998; 95: 12208-12213.

21. Hustert E, Zibat A, Presecan-Siedel E, Eiselt R, Mueller R, Fuss C, et al. Natural protein variants of pregnane $X$ receptor with altered transactivation activity toward CYP3a4. Drug Metab Dispos 2001; 29: $1454-1459$

22. Kliewer SA, Goodwin B, Willson TM. The nuclear pregnane X receptor: A key regulator of xenobiotic metabolism. Endocr Rev 2002; 23: 687-702.

23. Baes M, Gulick T, Choi HS, Martinoli MG, Simha D, Moore DD. A new orphan member of the nuclear hormone receptor superfamily that interacts with a subset of retinoic acid response elements. Mol Cell Biol 1994; 14: 1544-1552.

24. Alexander DL, Eltom SE, Jefcoate CR. Ah receptor regulation of CYP1b1 expression in primary mouse embryo-derived cells. Cancer Res 1997; 57: 4498-4506.

25. Hankinson O. Role of coactivators in transcriptional activation by the aryl hydrocarbon receptor. Arch Biochem Biophys 2005; 433: $379-386$

26. Nakata K, Tanaka Y, Nakano T, Adachi T, Tanaka H, Kaminuma $\mathrm{T}$, et al. Nuclear receptor-mediated transcriptional regulation in phase I, II, and III xenobiotic metabolizing systems. Drug Metab Pharmacokinet 2006; 21: 437-457.

27. Moore LB, Parks DJ, Jones SA, Bledsoe RK, Consler TG, Stimmel $\mathrm{JB}$, et al. Orphan nuclear receptors constitutive androstane receptor and pregnane $\mathrm{X}$ receptor share xenobiotic and steroid ligands. $J$ Biol Chem 2000; 275: 15122-15127.

28. Howe K, Sanat F, Thumser AE, Coleman T, Plant N. The statin class of HMG-CoA reductase inhibitors demonstrate differential activation of the nuclear receptors PXR, CAR and FXR, as well as their downstream target genes. Xenobiotica 2011; 41: 519-529.

29. Synold TW, Dussault I, Forman BM. The orphan nuclear receptor SXR coordinately regulates drug metabolism and efflux. Nat Med 2001; 7: 584-590.

30. Kobayashi K, Yamanaka Y, Iwazaki N, Nakajo I, Hosokawa M, Negishi M, et al. Identification of HMG-CoA reductase inhibitors as activators for human, mouse and rat constitutive androstane receptor. Drug Metab Dispos 2005; 33: 924-929.

31. Poland RE, Rubin RT. Radioimmunoassay of haloperidol in human serum: Correlation of serum haloperidol with serum prolactin. Life Sci 1981; 29: $1837-1845$.

32. Tontonoz P, Mangelsdorf DJ. Liver X receptor signaling pathways in cardiovascular disease. Mol Endocrinol 2003; 17: 985-993.

33. Jacobs MN, Dickins M, Lewis DF. Homology modelling of the nuclear receptors: Human oestrogen receptorbeta (HERbeta), the human pregnane-X-receptor (PXR), the aH receptor (AhR) and the constitutive androstane receptor (CAR) ligand binding domains from the human oestrogen receptor alpha (HERalpha) crystal structure, and the human peroxisome proliferator activated receptor alpha (PPARalpha) ligand binding domain from the human PPARgamma crystal structure. J Steroid Biochem Mol Biol 2003; 84: $117-132$.

34. Xie W, Barwick JL, Simon CM, Pierce AM, Safe S, Blumberg B, et al. Reciprocal activation of xenobiotic response genes by nuclear receptors SXR/PXR and CAR. Genes Dev 2000; 14: 3014-3023.

35. Wei P, Zhang J, Dowhan DH, Han Y, Moore DD. Specific and overlapping functions of the nuclear hormone receptors CAR and PXR in xenobiotic response. Pharmacogenomics J 2002; 2: 117 126

36. Moore JT, Moore LB, Maglich JM, Kliewer SA. Functional and structural comparison of PXR and CAR. Biochim Biophys Acta 2003; 1619: 235-238.

37. Forman BM, Tzameli I, Choi HS, Chen J, Simha D, Seol W, et al. Androstane metabolites bind to and deactivate the nuclear receptor CAR-beta. Nature 1998; 395: 612-615.

38. Kakizaki S, Yamazaki Y, Takizawa D, Negishi M. New insights on the xenobiotic-sensing nuclear receptors in liver diseases; CAR and PXR. Curr Drug Metab 2008; 9: 614-621.

39. Qatanani M, Zhang J, Moore DD. Role of the constitutive androstane receptor in xenobiotic-induced thyroid hormone metabolism. Endocrinology 2005; 146: 995-1002.

40. Ma X, Idle JR, Gonzalez FJ. The pregnane X receptor: From bench to bedside. Expert Opin Drug Metab Toxicol 2008; 4: 895-908.

41. Lichti-Kaiser K, Brobst D, Xu C, Staudinger JL. A systematic analysis of predicted phosphorylation sites within the human pregnane X receptor protein. J Pharmacol Exp Ther 2009; 331: 65-76.

42. Staudinger JL, Xu C, Biswas A, Mani S. Post-translational modification of pregnane X receptor. Pharmacol Res 2011; 64: 4-10.

43. Biswas A, Pasquel D, Tyagi RK, Mani S. Acetylation of pregnane $\mathrm{X}$ receptor protein determines selective function independent of ligand activation. Biochem Biophys Res Commun 2011; 406: 371376.

44. Hosseinpour F, Moore R, Negishi M, Sueyoshi T. Serine 202 regulates the nuclear translocation of constitutive active/androstane receptor. Mol Pharmacol 2006; 69: 1095-1102.

45. Denison MS, Pandini A, Nagy SR, Baldwin EP, Bonati L. Ligand binding and activation of the Ah receptor. Chem Biol Interact 2002; 
141: $3-24$.

46. Denison MS, Nagy SR. Activation of the aryl hydrocarbon receptor by structurally diverse exogenous and endogenous chemicals. Annu Rev Pharmacol Toxicol 2003; 43: 309-334.

47. Adachi J, Mori Y, Matsui S, Takigami H, Fujino J, Kitagawa H, et al. Indirubin and indigo are potent aryl hydrocarbon receptor ligands present in human urine. J Biol Chem 2001; 276: 31475-31478.

48. Sinal CJ, Bend JR. Aryl hydrocarbon receptor-dependent induction of CYP1a1 by bilirubin in mouse hepatoma HEPA 1c1c7 cells. Mol Pharmacol 1997; 52: 590-599.

49. Seidel SD, Winters GM, Rogers WJ, Ziccardi MH, Li V, Keser B, et al. Activation of the Ah receptor signaling pathway by prostaglandins. J Biochem Mol Toxicol 2001; 15: 187-196.

50. Zhang N. The role of endogenous aryl hydrocarbon receptor signaling in cardiovascular physiology. J Cardiovasc Dis Res 2011; 2: 91-95.

51. Boisvert WA, Santiago R, Curtiss LK, Terkeltaub RA. A leukocyte homologue of the IL-8 receptor CXCR-2 mediates the accumulation of macrophages in atherosclerotic lesions of LDL receptordeficient mice. J Clin Invest 1998; 101: 353-363.

52. Swales KE, Bishop-Bailey D. The potential use of the pregnane $\mathrm{X}$ receptor in cardiovascular therapy. Expert Rev Cardiovasc Ther 2012; 10: $1079-1082$

53. Wang X, Fang X, Zhou J, Chen Z, Zhao B, Xiao L, et al. Shear stress activation of nuclear receptor PXR in endothelial detoxification. Proc Natl Acad Sci USA 2013; 110: 13174-13179.

54. Swales KE, Moore R, Truss NJ, Tucker A, Warner TD, Negishi M, et al. Pregnane $\mathrm{X}$ receptor regulates drug metabolism and transport in the vasculature and protects from oxidative stress. Cardiovasc Res 2012; 93: 674-681.

55. Zhou J, Zhai Y, Mu Y, Gong H, Uppal H, Toma D, et al. A novel pregnane $\mathrm{X}$ receptor-mediated and sterol regulatory element-binding protein-independent lipogenic pathway. J Biol Chem 2006; 281: $15013-15020$

56. Spencer M, Yao-Borengasser A, Unal R, Rasouli N, Gurley CM, Zhu B, et al. Adipose tissue macrophages in insulin-resistant subjects are associated with collagen VI and fibrosis and demonstrate alternative activation. Am J Physiol Endocrinol Metab 2010; 299: E1016-E1027, doi:10.1152/ajpendo.00329.2010.

57. $\mathrm{Hu}$ G, Xu C, Staudinger JL. Pregnane X receptor is SUMOylated to repress the inflammatory response. J Pharmacol Exp Ther 2010; 335: $342-350$.

58. Wallace K, Cowie DE, Konstantinou DK, Hill SJ, Tjelle TE, Axon A, et al. The PXR is a drug target for chronic inflammatory liver disease. J Steroid Biochem Mol Biol 2010; 120: 137-148.

59. Cheng J, Shah YM, Ma X, Pang X, Tanaka T, Kodama T, et al. Therapeutic role of rifaximin in inflammatory bowel disease: Clinical implication of human pregnane $\mathrm{X}$ receptor activation. J Pharmacol Exp Ther 2010; 335: 32-41.

60. Ghose R, Guo T, Vallejo JG, Gandhi A. Differential role of tollinterleukin 1 receptor domain-containing adaptor protein in toll-like receptor 2-mediated regulation of gene expression of hepatic cytokines and drug-metabolizing enzymes. Drug Metab Dispos 2011; 39: $874-881$.

61. Ghose R, Omoluabi O, Gandhi A, Shah P, Strohacker K, Carpenter $\mathrm{KC}$, et al. Role of high-fat diet in regulation of gene expression of drug metabolizing enzymes and transporters. Life Sci 2011; 89: $57-64$.

62. Zhou C, Tabb MM, Nelson EL, Grun F, Verma S, Sadatrafiei A, et al. Mutual repression between steroid and xenobiotic receptor and NF-kappaB signaling pathways links xenobiotic metabolism and inflammation. J Clin Invest 2006; 116: 2280-2289.

63. Hofmann AF, Borgstroem B. The intraluminal phase of fat digestion in man: The lipid content of the micellar and oil phases of intestinal content obtained during fat digestion and absorption. J Clin Invest 1964; 43: 247-257.

64. Mihaylova B, Emberson J, Blackwell L, Keech A, Simes J, Barnes $\mathrm{EH}$, et al. The effects of lowering LDL cholesterol with statin therapy in people at low risk of vascular disease: Meta-analysis of individual data from 27 randomised trials. Lancet 2012; 380: 581-590.

65. Staudinger JL, Goodwin B, Jones SA, Hawkins-Brown D, MacKenzie KI, LaTour A, et al. The nuclear receptor PXR is a lithocholic acid sensor that protects against liver toxicity. Proc Natl Acad Sci USA 2001; 98: 3369-3374.

66. Xie W, Radominska-Pandya A, Shi Y, Simon CM, Nelson MC, Ong ES, et al. An essential role for nuclear receptors SXR/PXR in detoxification of cholestatic bile acids. Proc Natl Acad Sci USA 2001; 98: 3375-3380.

67. Uppal H, Toma D, Saini SP, Ren S, Jones TJ, Xie W. Combined loss of orphan receptors PXR and CAR heightens sensitivity to toxic bile acids in mice. Hepatology 2005; 41: 168-176.

68. Goodwin B, Gauthier KC, Umetani M, Watson MA, Lochansky MI, Collins JL, et al. Identification of bile acid precursors as endogenous ligands for the nuclear xenobiotic pregnane $\mathrm{X}$ receptor. Proc Natl Acad Sci USA 2003; 100: 223-228.

69. Zhou C, Verma S, Blumberg B. The steroid and xenobiotic receptor (SXR), beyond xenobiotic metabolism. Nucl Recept Signal 2009; 7: e001, doi:10.1621/nrs.07001.

70. Cheng X, Maher J, Dieter MZ, Klaassen CD. Regulation of mouse organic anion-transporting polypeptides (OATPs) in liver by prototypical microsomal enzyme inducers that activate distinct transcription factor pathways. Drug Metab Dispos 2005; 33: 1276-1282.

71. Maher JM, Cheng X, Slitt AL, Dieter MZ, Klaassen CD. Induction of the multidrug resistance-associated protein family of transporters by chemical activators of receptor-mediated pathways in mouse liver. Drug Metab Dispos 2005; 33: 956-962.

72. Petrick JS, Klaassen CD. Importance of hepatic induction of constitutive androstane receptor and other transcription factors that regulate xenobiotic metabolism and transport. Drug Metab Dispos 2007; 35: 1806-1815.

73. Kiuchi Y, Suzuki H, Hirohashi T, Tyson CA, Sugiyama Y. CDNA cloning and inducible expression of human multidrug resistance associated protein 3 (MRP3). FEBS Lett 1998; 433: 149-152.

74. Jigorel E, Le Vee M, Boursier-Neyret C, Parmentier Y, Fardel O. Differential regulation of sinusoidal and canalicular hepatic drug transporter expression by xenobiotics activating drug-sensing receptors in primary human hepatocytes. Drug Metab Dispos 2006; 34: $1756-1763$.

75. Olinga P, Elferink MG, Draaisma AL, Merema MT, Castell JV, Perez $\mathrm{G}$, et al. Coordinated induction of drug transporters and phase I and II metabolism in human liver slices. Eur J Pharm Sci 2008; 33: $380-389$.

76. Richert L, Tuschl G, Abadie C, Blanchard N, Pekthong D, Mantion $\mathrm{G}$, et al. Use of mRNA expression to detect the induction of drug metabolising enzymes in rat and human hepatocytes. Toxicol Appl Pharmacol 2009; 235: 86-96.

77. Kliewer SA, Moore JT, Wade L, Staudinger JL, Watson MA, Jones $\mathrm{SA}$, et al. An orphan nuclear receptor activated by pregnanes defines a novel steroid signaling pathway. Cell 1998; 92: 73-82.

78. Makishima M, Okamoto AY, Repa JJ, Tu H, Learned RM, Luk A, et al. Identification of a nuclear receptor for bile acids. Science 1999; 284: $1362-1365$.

79. Kassam A, Winrow CJ, Fernandez-Rachubinski F, Capone JP, Rachubinski RA. The peroxisome proliferator response element of the gene encoding the peroxisomal beta-oxidation enzyme enoylCoA hydratase/3-hydroxyacyl-CoA dehydrogenase is a target for constitutive androstane receptor beta/9-cis-retinoic acid receptormediated transactivation. J Biol Chem 2000; 275: 4345-4350.

80. Ueda A, Hamadeh HK, Webb HK, Yamamoto Y, Sueyoshi T, Afshari CA, et al. Diverse roles of the nuclear orphan receptor CAR in regulating hepatic genes in response to phenobarbital. Mol Pharmacol 2002; 61: 1-6.

81. Sui Y, Xu J, Rios-Pilier J, Zhou C. Deficiency of PXR decreases atherosclerosis in ApoE-deficient mice. J Lipid Res 2011; 52: $1652-1659$.

82. Gao J, Xie W. Pregnane X receptor and constitutive androstane receptor at the crossroads of drug metabolism and energy metabolism. Drug Metab Dispos 2010; 38: 2091-2095.

83. Roth A, Looser R, Kaufmann M, Blattler SM, Rencurel F, Huang $\mathrm{W}$, et al. Regulatory cross-talk between drug metabolism and lipid homeostasis: Constitutive androstane receptor and pregnane $\mathrm{X}$ receptor increase Insig-1 expression. Mol Pharmacol 2008; 73: $1282-1289$.

84. Hamlat N, Forcheron F, Negazzi S, del Carmine P, Feugier P, Bricca $\mathrm{G}$, et al. Lipogenesis in arterial wall and vascular smooth muscular cells: Regulation and abnormalities in insulin-resistance. Cardiovasc Diabetol 2009; 8: 64.

85. Lahtela JT, Arranto AJ, Sotaniemi EA. Enzyme inducers improve insulin sensitivity in non-insulin-dependent diabetic subjects. Diabetes $1985 ; 34$ : $911-916$.

86. Miao J, Fang S, Bae Y, Kemper JK. Functional inhibitory cross-talk between constitutive androstane receptor and hepatic nuclear factor-4 in hepatic lipid/glucose metabolism is mediated by competition for binding to the DR1 motif and to the common coactivators, GRIP-1 and PGC-1alpha. J Biol Chem 2006; 281: 14537-14546.

87. Carver LA, Hogenesch JB, Bradfield CA. Tissue specific expression of the rat Ah-receptor and ARNT mRNAs. Nucleic Acids Res 1994; 22: 3038-3044. 
88. Mehrabi MR, Steiner GE, Dellinger C, Kofler A, Schaufler K, Tamaddon F, et al. The arylhydrocarbon receptor (AhR), but not the AhR-nuclear translocator (ARNT), is increased in hearts of patients with cardiomyopathy. Virchows Arch 2002; 441: 481 -489.

89. Takahashi Y, Nakayama K, Shimojima T, Itoh S, Kamataki T. Expression of aryl hydrocarbon receptor (AhR) and aryl hydrocarbon receptor nuclear translocator (ARNT) in adult rabbits known to be non-responsive to cytochrome p-450 1a1 (CYP1a1) inducers. Eur J Biochem 1996; 242: 512-518.

90. Hankinson O. Dominant and recessive aryl hydrocarbon hydroxylase-deficient mutants of mouse hepatoma line, HEPA-1, and assignment of recessive mutants to three complementation groups. Somatic Cell Genet 1983; 9: 497-514.

91. Poland AP, Glover E, Robinson JR, Nebert DW. Genetic expression of aryl hydrocarbon hydroxylase activity: Induction of monooxygenase activities and cytochrome p1-450 formation by 2,3,7,8-tetrachlorodibenzo- $p$-dioxin in mice genetically "nonresponsive" to other aromatic hydrocarbons. J Biol Chem 1974; 249: 5599-5606.

92. Nebert DW, Gielen JE. Genetic regulation of aryl hydrocarbon hydroxylase induction in the mouse. Fed Proc 1972; 31: 1315 1325.

93. Vogel CF, Sciullo E, Matsumura F. Activation of inflammatory mediators and potential role of Ah-receptor ligands in foam cell formation. Cardiovasc Toxicol 2004; 4: 363-373.

94. Liu S, Abdelrahim M, Khan S, Ariazi E, Jordan VC, Safe S. Aryl hydrocarbon receptor agonists directly activate estrogen receptor alpha in MCF-7 breast cancer cells. Biol Chem 2006; 387: 12091213.

95. Ohtake F, Takeyama K, Matsumoto T, Kitagawa H, Yamamoto Y, Nohara K, et al. Modulation of oestrogen receptor signalling by association with the activated dioxin receptor. Nature 2003; 423: $545-550$.

96. Schlezinger JJ, Liu D, Farago M, Seldin DC, Belguise K, Sonenshein GE, et al. A role for the aryl hydrocarbon receptor in mammary gland tumorigenesis. Biol Chem 2006; 387: 1175-1187.

97. Zhang S, Lei P, Liu X, Li X, Walker K, Kotha L, et al. The aryl hydrocarbon receptor as a target for estrogen receptor-negative breast cancer chemotherapy. Endocr Relat Cancer 2009; 16: 835-844.

98. Vogel CF, Sciullo E, Wong P, Kuzmicky P, Kado N, Matsumura F. Induction of proinflammatory cytokines and C-reactive protein in human macrophage cell line U937 exposed to air pollution particulates. Environ Health Perspect 2005; 113: 1536-1541.

99. Pelclova D, Fenclova Z, Preiss J, Prochazka B, Spacil J, Dubska Z, et al. Lipid metabolism and neuropsychological follow-up study of workers exposed to 2,3,7,8- tetrachlordibenzo-p-dioxin. Int Arch Occup Environ Health 2002; 75(Suppl): S60-S66.

100. Mathiesen M, Pedersen EK, Bjorseth O, Egeberg KW, Syversen T. Heating of indoor dust causes reduction in its ability to stimulate release of IL-8 and TNFalpha in vitro compared to non-heated dust. Indoor Air 2004; 14: 226-234.

101. Wu D, Nishimura N, Kuo V, Fiehn O, Shahbaz S, Van Winkle L, et al. Activation of aryl hydrocarbon receptor induces vascular inflammation and promotes atherosclerosis in apolipoprotein $\mathrm{E}^{-1-}$ mice. Arterioscler Thromb Vasc Biol 2011; 31: 1260-1267.

102. Schlezinger JJ, Stegeman JJ. Dose and inducer-dependent induction of cytochrome p450 1a in endothelia of the eel, including in the swimbladder rete mirabile, a model microvascular structure. Drug Metab Dispos 2000; 28: 701-708.

103. Wang N, Yin R, Liu Y, Mao G, Xi F. Role of peroxisome proliferator-activated receptor-gamma in atherosclerosis: An update. Circ J 2011; 75: 528-535.

104. Cheang WS, Fang X, Tian XY. Pleiotropic effects of peroxisome proliferator-activated receptor gamma and delta in vascular diseases. Circ J 2013; 77: 2664-2671.

105. Oesterling E, Toborek M, Hennig B. Benzo[a]pyrene induces intercellular adhesion molecule-1 through a caveolae and aryl hydrocarbon receptor mediated pathway. Toxicol Appl Pharmacol 2008; 232: $309-316$.

106. Watanabe I, Tatebe J, Namba S, Koizumi M, Yamazaki J, Morita T. Activation of aryl hydrocarbon receptor mediates indoxyl sulfateinduced monocyte chemoattractant protein-1 expression in human umbilical vein endothelial cells. Circ J 2013; 77: 224-230.

107. Coogan PF, White LF, Jerrett M, Brook RD, Su JG, Seto E, et al. Air pollution and incidence of hypertension and diabetes mellitus in black women living in Los Angeles. Circulation 2012; 125: 767-772.

108. Lund AK, Agbor LN, Zhang N, Baker A, Zhao H, Fink GD, et al. Loss of the aryl hydrocarbon receptor induces hypoxemia, endothelin-1, and systemic hypertension at modest altitude. Hypertension 2008; 51: 803-809.
109. Kopf PG, Huwe JK, Walker MK. Hypertension, cardiac hypertrophy, and impaired vascular relaxation induced by 2,3,7,8-tetrachlorodibenzo- $p$-dioxin are associated with increased superoxide. Cardiovasc Toxicol 2008; 8: 181-193.

110. Kang HK, Dalager NA, Needham LL, Patterson DG Jr, Lees PS, Yates K, et al. Health status of Army Chemical Corps Vietnam veterans who sprayed defoliant in Vietnam. Am J Ind Med 2006; 49: $875-884$

111. Kim JS, Lim HS, Cho SI, Cheong HK, Lim MK. Impact of agent orange exposure among Korean Vietnam veterans. Ind Health 2003; 41: $149-157$

112. Dalton TP, Kerzee JK, Wang B, Miller M, Dieter MZ, Lorenz JN, et al. Dioxin exposure is an environmental risk factor for ischemic heart disease. Cardiovasc Toxicol 2001; 1: 285-298.

113. Pesatori AC, Zocchetti C, Guercilena S, Consonni D, Turrini D, Bertazzi PA. Dioxin exposure and non-malignant health effects: A mortality study. Occup Environ Med 1998; 55: 126-131.

114. Lund AK, Goens MB, Kanagy NL, Walker MK. Cardiac hypertrophy in aryl hydrocarbon receptor null mice is correlated with elevated angiotensin II, endothelin-1, and mean arterial blood pressure. Toxicol Appl Pharmacol 2003; 193: 177-187.

115. Agbor LN, Elased KM, Walker MK. Endothelial cell-specific aryl hydrocarbon receptor knockout mice exhibit hypotension mediated, in part, by an attenuated angiotensin II responsiveness. Biochem Pharmacol 2011; 82: 514-523.

116. Kopf PG, Walker MK. 2,3,7,8-tetrachlorodibenzo-p-dioxin increases reactive oxygen species production in human endothelial cells via induction of cytochrome p4501a1. Toxicol Appl Pharmacol 2010; 245: 91-99.

117. Kimura A, Naka T, Nohara K, Fujii-Kuriyama Y, Kishimoto T. Aryl hydrocarbon receptor regulates STAT1 activation and participates in the development of Th17 cells. Proc Natl Acad Sci USA 2008; 105: $9721-9726$.

118. Guzik TJ, Hoch NE, Brown KA, McCann LA, Rahman A, Dikalov $\mathrm{S}$, et al. Role of the $\mathrm{T}$ cell in the genesis of angiotensin II induced hypertension and vascular dysfunction. J Exp Med 2007; 204: $2449-2460$.

119. Mani S, Dou W, Redinbo MR. PXR antagonists and implication in drug metabolism. Drug Metab Rev 2013; 45: 60-72.

120. Chen $\mathrm{T}$. Overcoming drug resistance by regulating nuclear receptors. Adv Drug Deliv Rev 2010; 62: 1257-1264.

121. Wang XL, Raveendran M, Wang J. Genetic influence on cigaretteinduced cardiovascular disease. Prog Cardiovasc Dis 2003; 45: $361-382$.

122. Zordoky BN, El-Kadi AO. Effect of cytochrome p450 polymorphism on arachidonic acid metabolism and their impact on cardiovascular diseases. Pharmacol Ther 2010; 125: 446-463.

123. Bozina N, Bradamante V, Lovric M. Genetic polymorphism of metabolic enzymes p450 (CYP) as a susceptibility factor for drug response, toxicity, and cancer risk. Arh Hig Rada Toksikol 2009; 60: $217-242$

124. Kazui M, Nishiya Y, Ishizuka T, Hagihara K, Farid NA, Okazaki $\mathrm{O}$, et al. Identification of the human cytochrome p450 enzymes involved in the two oxidative steps in the bioactivation of clopidogrel to its pharmacologically active metabolite. Drug Metab Dispos 2010; 38: $92-99$

125. Lau WC, Gurbel PA, Watkins PB, Neer CJ, Hopp AS, Carville DG, et al. Contribution of hepatic cytochrome p450 3a4 metabolic activity to the phenomenon of clopidogrel resistance. Circulation 2004; 109: $166-171$

126. Hagedorn KA, Cooke CL, Falck JR, Mitchell BF, Davidge ST. Regulation of vascular tone during pregnancy: A novel role for the pregnane X receptor. Hypertension 2007; 49: 328-333.

127. Huang $\mathrm{W}$, Zhang J, Moore DD. A traditional herbal medicine enhances bilirubin clearance by activating the nuclear receptor CAR. J Clin Invest 2004; 113: 137-143.

128. Moore LB, Goodwin B, Jones SA, Wisely GB, Serabjit-Singh CJ, Willson TM, et al. St. John's wort induces hepatic drug metabolism through activation of the pregnane X receptor. Proc Natl Acad Sci USA 2000; 97: 7500-7502.

129. Cheng TO. Cardiovascular effects of danshen. Int J Cardiol 2007; 121: $9-22$.

130. Yu C, Ye S, Sun H, Liu Y, Gao L, Shen C, et al. PXR-mediated transcriptional activation of CYP3a4 by cryptotanshinone and tanshinone IIa. Chem Biol Interact 2009; 177: 58-64.

131. Chang TK. Activation of pregnane X receptor (PXR) and constitutive androstane receptor (CAR) by herbal medicines. AAPS J 2009; 11: $590-601$

132. Graham MJ, Lake BG. Induction of drug metabolism: Species differences and toxicological relevance. Toxicology 2008; 254: 184- 
191.

133. Folts JD. Potential health benefits from the flavonoids in grape products on vascular disease. Adv Exp Med Biol 2002; 505: $95-$ 111.

134. Medjakovic S, Jungbauer A. Red clover isoflavones biochanin A and formononetin are potent ligands of the human aryl hydrocarbon receptor. J Steroid Biochem Mol Biol 2008; 108: 171-177.

135. Shan Y, Zhao R, Geng W, Lin N, Wang X, Du X, et al. Protective effect of sulforaphane on human vascular endothelial cells against lipopolysaccharide-induced inflammatory damage. Cardiovasc Toxicol 2010; 10: 139-145.

136. Anwar-Mohamed A, El-Kadi AO. Sulforaphane induces CYP1a1 mRNA, protein, and catalytic activity levels via an AhR-dependent pathway in murine hepatoma HEPA1c1c7 and human HEPG2 cells. Cancer Lett 2009; 275: 93-101.

137. Gielen JE, Nebert DW. Aryl hydrocarbon hydroxylase induction in mammalian liver cell culture. I: Stimulation of enzyme activity in nonhepatic cells and in hepatic cells by phenobarbital, polycyclic hydrocarbons, and 2,2-bis( $p$-chlorophenyl)-1,1,1-trichloroethane. $J$ Biol Chem 1971; 246: 5189-5198.

138. Zatloukalova J, Svihalkova-Sindlerova L, Kozubik A, Krcmar P, Machala M, Vondracek J. Beta-naphthoflavone and 3'-methoxy-4'nitroflavone exert ambiguous effects on Ah receptor-dependent cell proliferation and gene expression in rat liver 'stem-like' cells.
Biochem Pharmacol 2007; 73: $1622-1634$.

139. Barouki R, Coumoul X, Fernandez-Salguero PM. The aryl hydrocarbon receptor, more than a xenobiotic-interacting protein. FEBS Lett 2007; 581: $3608-3615$

140. Bittinger MA, Nguyen LP, Bradfield CA. Aspartate aminotransferase generates proagonists of the aryl hydrocarbon receptor. $\mathrm{Mol}$ Pharmacol 2003; 64: 550-556.

141. Zhou C, King N, Chen KY, Breslow JL. Activation of PXR induces hypercholesterolemia in wild-type and accelerates atherosclerosis in ApoE deficient mice. J Lipid Res 2009; 50: 2004-2013.

142. Sberna AL, Assem M, Xiao R, Ayers S, Gautier T, Guiu B, et al Constitutive androstane receptor activation decreases plasma apolipoprotein B-containing lipoproteins and atherosclerosis in low density lipoprotein receptor-deficient mice. Arterioscler Thromb Vasc Biol 2011; 31: 2232-2239.

\section{Supplementary Files}

Supplementary File 1

Non-standard abbreviations and acronyms

Please find supplementary file(s);

http://dx.doi.org/10.1253/circj.CJ-14-0343 